\title{
A REFLECTION ON THE LEGACIES OF CHARLES DARWIN
}

J M Agai

\section{University of Kwa Zulu-Natal}

\begin{abstract}
The biological theory of human evolution existed before Charles Darwin. His view on the origins of animals attracted much debate among scientists and Christians since 1859. Darwin's view on the causes of variation among species which led to the emergence of humans has contributed to the development of an ideology according to which he is the father of evolution. This research is a historical reflection on Darwin's life and his theory of evolution. The author describes the views that existed and still exist as responses to Darwin's life and his theory of evolution. The research is aimed at appreciating Darwin's legacies and his contribution to the development of the various schools of thoughts among Christians regarding the creation/evolution debate.
\end{abstract}

Key Words: Creation, Creationism, Evolution, Evolutionism, Fundamentalism, Theistic Evolutionism

\section{INTRODUCTION}

The recent comments made by Pope Francis in the Vatican attracted mix reactions from Christian and non-Christian audiences. The Pope said that with regard to creation, God should not be tagged a magician. He emphasized that Christians should believe in both creation and evolution because the two concepts do not contradict each other. He said "[w]hen we read the creation story in Genesis we run the risk of imagining that God was a magician, with a magic hand which is able to do everything.... But it is not so. He created beings and let them develop according to internal laws which 
He gave every one, so they would develop, so they would reach maturity" (Davies 2014:1). Before the year 2014, Russell Grigg taught that regarding evolution and creation as similar processes cannot be true (Grigg 2012:1). While some conservative Christians disagreed with the Pope's evolutionary concept, other Christians especially those who are liberal, appreciated the Pope's courage for the comments he made.

Generally, the most renowned figure behind the theory of evolution is Charles Darwin. Although the theory was discussed two generations earlier (by Erasmus Darwin (1794) and Jean Lamarck (1809)) before Charles Darwin, his publication On Origins of Species (1859) contributed immensely to the global popularity of the concept (Sheldrake 1984:20). Recently, Cunningham and Saigo described Darwin as the father of the theory of natural selection (Cunningham \& Saigo 1990:563). It seems Darwin's name is frequently associated with the evolution and the creation debate than the name of any specific individual after 1859. In 1860, the Anglican Bishop of Oxford, Samuel Wilberforce said "... if Darwin's Thesis [of evolution] is true, then Genesis is a lie..." (Nemesszhy \& Russel 1972:10). C.H. Spurgeon (1834-1892), one of England's best preachers in the nineteenth century also called the biological theory of human evolution "monstrous error" (Dowley \& Briggs 1990:549-550). Many scholars believed that Wilberforce's arguments were baseless because he had no knowledge of biology despite his association with a zoologist, Richard Owen (Darwin 1987:512).

After the publication On the Origin of Species, some Christians regarded Darwin as an atheist while others did not (cf. Grigg 2012:4). In other words, while many individuals regarded Darwin as an evidence based scientist who brought about much enlightenment on the subject of creation, others 
saw him as a devil (Williams, Clough, Stanley \& Colbert 2016:1).

In the African society where traditional views regarding the origin of humans exist, mixed reactions also trails on Darwin and his views of the human origin. Africans rely on oral traditions to explain their creation or origins (Oyebade 2004:52). Africans believe that God is directly responsible for creating humans. They distaste the association of human origin from brutes. The Yorubas for example have a tradition according to which God (Olorun) created the first human (Oduduwa) directly from heaven and sent him to lle Ife, a renowned Yorubaland (Ojo 2004:5). Some Africans believe in the biblical and the African traditional account of creation while some in Darwin's theory of evolution due to the fact that it is taught in African schools. Others believe in one or two or all of these accounts of the formation of humans. However, many Christians in Africa read the creation account from a conservative perspective where evolutionary processes were not involved.

Archaeological remains of early humans or the cotemporaries of early humans have been found in Africa. The remains of the Rhodesian man found in a cave north of the river Zambesi, and those found in Saldanha in South Africa, Ngaloba in Tanzania, Bodo and the Omo valley in Ethiopia have added interest on the study of the biological theory of human evolution among Africans. Acheulian materials in the form of cleavers together with other tools made-up of bones, stones and woods found in Nigeria have made archaeologists to suggest that early humans like Homo Erectus and others lived in West Africa (Agai 2013:3, 5-6). More so, Daniël P. Veldsman of the Department of Dogmatics and Christian Ethics, University of Pretoria said that a new fossil called Homo Naledi found in the Dinaledi Chamber of the rising star cave in Gauteng, South Africa have contributed to the soteriological debate on 
the distinctiveness between modern humans and pre-humans (Veldsman 2016:2-7). These and many other archaeological findings made in Africa have directly or indirectly influenced Africans to debate and to accept or reject the view according to which humans originated from brutes.

Over the years, Christians debated whether Darwin's evolutionary theory contradicted the biblical account of creation. The debate stirred interest among scientists and Christians on the view according to which science contradicted the Christian faith. Since 1859, Darwin had been at the center of this argument and as a result, some Christians regarded his theory of human origin as heretical. This research is a discourse on how Christians have responded to Darwin and his theory of evolution, particularly his views of the human origins after 1871 in Descent of Man. The research shall be focused on Christian responses to Darwin's theory of evolution from the United States of America and from Europe in the eighteenth, nineteenth and twentieth centuries.

\section{Darwin's Biography}

\subsection{Darwin's Background (1809-1831)}

February 12, 1809 was a very significant day in the history of the world. This is because the most popular man behind the theory of evolution, Charles Darwin, and one of America's most popular presidents, Abraham Lincoln, were both born on the same day that year. Darwin was born in Shrewsbury, England, while Lincoln was born in rural Kentucky (Davidheiser 1969:56-57). The year 1809 is also significant because it was in this same year that the French scientist Jean Baptiste Lamarck put forward his own theory of evolution (Sheldrake 1984:20). One cannot talk about the history of biological evolution in complete without mentioning Jean Baptiste Lamarck (1744-1929) who contributed greatly to the 
knowledge before Charles Darwin. Lamarck was a French naturalist who in 1889 published his book Philosophy of Zoology where he expounded his theory of evolution. He was the first person to introduce a complete theory of evolution that was scientifically certified in the nineteenth century (Davidheiser 1969:49).

Lamarck propounded two laws of evolution. The first law has to do with the use and disuse of organs. The law state that organs often used by an organism are strengthened while organs not used by an organism become weaker and gradually disappear. His second law deals with the inheritance of acquired characteristics. The law states that any animal has the tendency to transfer acquired characteristics gained during its lifetime to its offspring (Welch 1963: 65-67). He cited an example with the giraffe which to him had shorter necks and that the necks were strengthened and made longer due to a constant stretching of their necks in the search for leaves on trees (Ramlingam 2001:525). Ernest Haeckel, an aggressive proponent of evolution, described Lamarck as the founder of the theory of descent. Despite Lamarck's prominence and earlier acceptability, almost all recent scientists disagree with his second law mainly because it cannot be scientifically proven (Ramlingam 2001:67).

It is important to note that before Darwin brought forth his theory of evolution, his grandfather Erasmus Darwin had knowledge of the concept. But Erasmus' view was not widely popular in comparison to Charles. Erasmus wrote The Botanic Garden (1791) where he described the classification system of Linnaeus and he also wrote Zoomania where he described the idea of the evolution of species (Lamoureux 2015:2; Darwin 1987: 508). Like Aristotle who believed in an intelligent designer who created the world (Boer 1976:7-8), Carolus Linnaeus (1707-1779), a Swedish biologist named 
4,235 animal species and 5,250 plant species. He believed that every living thing is created by a Creator and that the resemblance seen in man and apes and to monkeys shows that they are of the same descent from a particular ancestor (Evolution 1987:274). More so, Linnaeus and some of his contemporaries like the Swiss naturalist, Charles Bonnet (17201790), believed in what they called a great chain or ladder of being which suggests a chain of progressive development from inanimate objects to animate: "...corals, polyps, plants, invertebrate animals, fishes, birds, mammals, monkeys, to men"' (Evolution 1987:274).

Charles Darwin's father, Robert Waring Darwin and his grandfather were both physicians. However, Erasmus was a popular poet-physician-philosopher. Darwin's mother Susanna Wedgwood was the daughter of the much celebrated potter Josiah Wedgwood. She attended Church together with her children because she was a committed Christian (Lamoureux 2015:2; Darwin 1987: 508). Charles Darwin started his full academic career in 1818 when he attended Shrewsbury School (Davidheiser 1969:58). But he was unserious about his studies, so he was asked by his father to leave Shrewsbury School in 1825 in order to study medicine at Edinburgh University (Williams, Clough, Stanley \& Colbert 2016:1). He could not cope with school for some reasons. Firstly, he was interested in playing with animals. His father once said to him, "[y]ou care for nothing but shooting, dogs and rat catching and you will be a disgrace to yourself and all your family" (Davidheiser 1969:58). Secondly, he lacked the courage to watch surgical operations which at that time were conducted without anesthesia (Davidheiser 1969:67). Thirdly, there was no discipline in the college he attended: "[i]t is said that at this time the school was noted for gambling, drunkenness, moral laxity, and lack of discipline" (Davidheiser 
1969:58). Whye, a senior lecturer and director of Darwin Online at National University of Singapore also so said that during Darwin's days at Christ College, there was no rigorous academic and strict religious discipline on the students (Wyhe 2009:2).

John van Wyhe disagreed with those who believe that Darwin studied theology. He said: "It is often said that Darwin studied theology or divinity at Cambridge. This is not correct. Darwin was a candidate of an ordinary Bachelor of Arts degree, or B.A. After the B.A. he could have taken divinity training before taking Holy Orders. Darwin never undertook the divinity training" (Wyhe 2009:2-3). However, many more scholars have argued that Darwin studied theology. For example, Davidheiser, a creationist zoologist said that Darwin was sent to study theology at Christ's College, Cambridge in 1827 with the aim that he might prepare for holy orders in the Church of England. But to the surprise of many, Darwin had little or no time for his ministerial work and studies; rather he preferred spending most of his time with sportsmen and acquainting himself with many scientists who motivated his interest in the study of natural history. He graduated with a B.A. degree in 1831 (Davidheiser 1969:67). In his writings especially On Origin of Species, Darwin seemed to have exercised extreme caution not to dissociate himself or his views from the Bible and the Church.

His caution might have been due to the fact that his mother influenced his thoughts by dedicating him regularly to attending Church activities. More so, his interests in exercising caution to associate creation with a designer have been influenced by William Paley (1743-1805). William Paley in Natural Theology; or Evidences of the Existence and Attributes of the Deity, Collected from the Appearances of Nature argued 
for the existence of God fundamentally due to the orderly design of the universe. Darwin said that he admired Paley's theory of connecting creation with a designer (Paley 1802:1-3). Darwin noted "I do not think I hardly ever admired a book more than Paley's 'Natural Theology.'... I could almost formerly have aid it by heart" (Grigg 2012:1). However, at the later stage of his life, he struggled in his mind whether to believe in God or not. He finally became an agnostic (Grigg 2012:1).

2.2 Darwin's HMS Beagle Voyage and Afterward (18311882)

One prominent scientist who influenced Darwin was John Stevens Henslow, a priest and professor of Botany. While in Christ's College, Darwin was intimate with Henslow. He was intimate to the point that he was called "[t]he man who walks with Henslow" (Davidheiser 1969:58). Also, Adam Sedgwick, a Professor of Geology and former president of the Geological Society of London influenced Darwin's interest in geological research (Williams, Clough, Stanley \& Colbert 2016:1). Professor Henslow recommended Darwin to participate in a scientific expedition around the world on H.M.S. Beagle. The voyage gave Darwin the opportunity to observe and study natural processes and also developed his interest in the study of plants and animals. Darwin collected many beetles and he studied their physical features (Wyhe 2009:9-11). The voyage on the Royal Navy Ship, H.M.S. Beagle, commenced from Devonport in England on December 27, 1831, under the leadership of Captain Robert Fitzroy. Darwin's duty during the voyage was to serve as an official naturalist who would study

${ }^{1}$ Quoted from Life and Letters of Charles Darwin, C. Darwin to John Lubbock, 15 November, 1859, D. Appleton and Co., New York. 
rocks; the nature of places visited and undertakes the collection of specimens (Lamoureux 2015: 3; Darwin 1987:509.)

Darwin's first geological observations were on the structure of the Cape Verde Islands. He was able to prove the nature of the elevation and subsidence of Sao Tiago Island. He showed that there was a time when the mountain was elevated but due to factors like weathering, it subsided. While in Argentina, Darwin explained why sedimentary rocks crystallize when they are metamorphosed by the pressure beneath other rocks. In Chile, he observed the implications of earthquakes and volcanic eruptions in raising the ground level. Darwin contributed to geological studies: "Darwin's observations of geological elevation and subsidence led him to propose a theory, now generally accepted, that explains how coral reefs are formed" (Darwin1987:509).

In 1835, during the voyage, Darwin collected 31 specimens of finch from three different islands all within the Galapagos Islands off the coast of Ecuador. Darwin had difficulties in identifying the specimens because of their similarities so he started a thorough examination of their bills. He observed that some of the finches have larger bills because they fed on seeds which they crushed with their beaks. Other finches he observed had narrow bills, which they use to eat insects. Some were fruit eaters, while others ate cactus, yet another was a vampire that used its sharp beak to drink the blood of seabirds (cf. Raven \& Johnson 1999:40). Darwin continued his observations on his return to England in 1836 and concluded that all birds must have had a common ancestor but their diversity was as a result of natural selection. Darwin thought that the 13 varied finch species he collected were a clear example of the effect of natural selection. He propounded that: 
The correspondence between the beaks of the 13 finch species and their food immediately suggested to Darwin that evolution had shaped them... Among Darwin's finches, natural selection adjusted the shape of the beak in response to the nature of available food supply, adjustments which can be seen to be occurring even today (Raven \& Johnson 1999:410- 411).

In addition, Darwin collected quite a number of fossils of the skeletal systems of certain animals and saw many similarities between the fossils and the skeletal systems of living animals. When he was trying to record the differences between ranges of species, he then observed that "... different yet clearly related species occupied adjacent areas of a continent..." (Darwin 1987: 509).

The H.M.S. Beagle arrived at Falmouth, England, in October 2, 1836. Darwin started formal recording of his observation from July 1837. He started with Notebooks on the Transmutation of Species where he indirectly showed some evidence of evolution like comparative anatomy, instincts, geographical distribution, etc. Darwin was also influenced by Thomas Malthus' theory of population (that food supply increases at an arithmetic rate while population increases at a geometric rate). He read Malthus' work Essay on the Principle of Population on September 28, 1838 (Darwin 1987: 509). Darwin is quoted to have said that:

In October $1838 \ldots$ I happened to read for amusement "Malthus on Population," and being well prepared to appreciate the struggle for existence which everywhere goes on from long-continued observation of the habits of animals and plants, it at once struck me that under these circumstances favourable variations would tend to be preserved, and unfavourable once to be destroyed. The results of this would be the formation of new species. Here then I had at last got a theory by which to work... (Williams, Clough, Stanley \& Colbert 2016:4). 
In 1842, Darwin wrote a sketch of his theory of evolution and sent it to Joseph Dalton, a well-known botanist. His formal writing concerning species continued till May 14, 1856, On June 18, 1858, Darwin received a letter from Alfred Russel Wallace. The letter was a summary of the theory of evolution by means of natural selection which Wallace had composed for himself (Darwin 1987:509). Darwin wished he had published his work before then. However, Lyell and Sir Joseph Hooker, who had already read Darwin's work, were ready to help both scientists publish their works. Hooker organized a reading of a joint paper by both Darwin and Wallace to the Linnaen Society of London on July 1, 1859 (Williams, Clough, Stanley \& Colbert 2016:1; “Darwin” 1987:509).

Darwin later wrote various publications in other to voice out his views about the origin of species. He wrote The Variation of Animals and Plants under Domestication (1868), the Expression of the Emotions in Man and Animals 1872, etc. He wrote other books that dealt with plants: On the Various Contrivances by which British and Foreign Orchards Are Fertilized by Insects (1862), the Effects of Cross-Fertilization in the Vegetable Kingdom (1876). With the aid of his son Sir Francis Darwin, who became a popular botanist, Charles Darwin wrote The Power of Movement in Plants (Darwin 1979:41). Darwin's additional writings contributed to his popularity. Darwin got married to his first cousin Emma Wedgwood on January 29, 1839 and had ten children, three of whom died in infancy. Darwin died at Downe, Kent in England on April 19, 1882 and was buried in West- minister Abbey on April 26, 1882 (Lamoureux 2015:7-8; cf. Darwin 1987: 509). 


\section{Darwin's Legacies}

\subsection{On His Scientific Researches}

On The Origin of Species by Means of Natural Selection was published by Charles Darwin in 1859. Darwin said that the main causes of variation in species are environment and genetic inheritance (Darwin 1952:230). Contrary to his initial belief in a creator, he thought that the best explanation for variation in species cannot be explained by the biblical creation account. He said “... It must be admitted that these facts [variation among organisms] receive no explanation on the theory of creation" (Darwin 1952:239). He added "I see no good reason why the views in this volume should shock the religious feelings of any one" (Darwin 1952:239). Darwin compared himself with Isaac Newton whose theory on the law of gravity was firstly rejected thinking that his theory of evolution may initially be rejected. He also cited an example of Leibniz who accused Newton of introducing "occult qualities and miracles into philosophy" (Darwin 1952:239). In addition, Darwin said that Galileo's idea of the earth's revolution was not accepted because it was not supported by any fundamental evidence but it is accepted during his time and in the present because there is enough evidence to prove the revolution of the earth (Darwin 1952:239).

In his Descent of Man and the Selection in Relation to Sex published in 1871, Darwin emphasized the theory of decent which led to the formation of humans. He said:

We thus learn that man is descended from a hairy, tailed quadruped, probably arboreal in its habits and an inhabitant of the Old World... and all the higher mammals are probably derived from an ancient marsupial animal, and this through a long series of diversified forms, from some amphibian-like creature, and this again from some fish-like 
animal... But there can hardly be a doubt that we are descended from barbarians (Darwin 1952:594).

In the field of biology, Darwin's view on human origins has motivated so many biological scientists to get more involved in research in areas like morphology, embryology, and palaeontology. Welch said that, at the time of Darwin, the study of ecology had been abandoned for about 50 years, and that it was Darwin's research that re-motivated the study of ecology (Welch 1963:75). Raven and Johnson noted that Darwin's theory of evolution is widely accepted by biologists as the best available explanation for biological variation among organisms of the same and different species (Raven \& Johnson 1999:420). As part of his achievement, Darwin's "[t]heory of evolution was the first general principle established in biology." Furthermore, "It was Darwin who was chiefly responsible for introducing such 'population thinking' into biology since natural selection has no meaning at all except in a population showing genetic variation" (Darwin 1987: 508).

Neo-Darwinism is a concept according to which the main cause of variation in an organism is competitive mutation in genes (Dawkins 2004). The concept of Neo-Darwinism did not contradict Darwin's theory of evolution; rather it complemented the theory. Neo-Darwinism de-emphasized the physical environment as the main factor for variation and modification among organisms. The fact of genetic change is the pivot for Neo-Darwinism:

When Charles Darwin proposed his theory of evolution by natural selection, he was not given the advantage of genetics to help explain and support his theory. The development of genetic research and molecular biology in the last fifty years have reinforced and explained the mechanism and intricacies of Darwin's theory. Genetics has shown that organisms are not fixed and their genotypes, and ultimately their phenotypes, can sometimes undergo 
positive change, which supports the theory of evolution (Agarwal, Hyland \& Smith 1998).

It is the search for the main mechanism for variation among organisms that led to the emergence of the concept of NeoDarwinism. Though it started around the 1920s and 1930s, initially propagated by Ronald A. Fisher, J.B.S. Haldane, and Sewall Wright, Neo-Darwinism was later consolidated in 1940. After Darwin's death, he was honoured by being buried with England's great men of honour (Darwin 1979:41). Also, Karl Marx initially intended to dedicate his book Das Kapital in honour of Darwin but Darwin refused because he thought that Marx's idea of capitalism was strictly atheistic, and according to Gertrude Himmelfarb, Darwin did not want to associate himself with an atheist. In 1959, Darwin's centennial year, the communists honoured Darwin with a medal and his picture on their postage stamp (Davidheiser 1969:70). In 2003, CNN reported that Charles Darwin was honoured among Britain's ten great men of the nineteenth century (CNN, "Britain's 10 Great Men," 2003).

\subsection{On the Christian Worldview of Creation/Evolution}

\subsubsection{The Christian Evolutionists Movement}

The theistic evolutionists are Christians who believe in two theories of creation. Firstly, they think that God created all things from pre-existing matter (Mixter 1960:185). They are of the opinion that microscopic life, started immediately after the creation of the heaven and the earth as recorded in the Genesis account. The theistic evolutionary view correlates with the scientific notion according to which life started after the formation of the earth, and that the first photosynthesizers found in rocks about 3.5 billion years suggest the beginning of microscopic lives (Rust \& Held 1999:231-234, 240). Secondly, very few among them think that God created matter out 
of nothing (ex nihilo) (the theory according to which God created out of nothing). That God allowed what He created to undergo through evolutionary changes. Early church apologists like Justin Martyr, Theophilus of Antioch, Irenaeus and Tertullian believed that God created matter out of nothing. Tertullian in particular also mentioned that the issue of whether God created out of nothing or from pre-existing matter has not been made clear by Bible writers (Overman 1952:247-248).

The Roman Catholic Church for example did not condemn the theory of evolution even after Darwin's publication On Origin of Species (Nemesszeghy \& Russel 1972:48). They rather disagreed with Aristotle theory of the spontaneous generation of humans from minute organisms. Aristotle in the fourth century BCE thought that the first life on earth came into being spontaneously by itself from non-living matter catalysed by a force called "active principle" (Welch 1963:87). Darwin taught that animals and humans emerged from some four or five ancestors "[i] believe that animals are descended from at most only four or five progenitors and plants from an equal or lesser number" (Darwin 1952:231). The Roman Catholic Church on the other hand believed that Adam and Eve were the first humans created on earth and that the Original Sin which affected all humans was committed by them (Romans 5:12; Nemesszeghy \& Russel 1972:42-43). A year after the publication of the Origin of Species, the Provincial Council of Cologne (1860) at a meeting agreed that:

Our first parents were immediately made by God. Thus we declare plainly opposed to the Scripture and to faith the opinion of those who go so far as to say that man, even as his body is concerned, was produced by the spontaneous transformation of the less perfect into the more perfect 
successively, ultimately ending in the human (Nemesszeghy \& Russel 1972:42-43, originally from Titius IV, Cap. 14).

More so, since 1950, Catholic authors, for example, “... have put forward ideas accepting man's evolutionary origins without any interference on the part of the ecclesiastical authority" (Nemesszhy \& Russel 1972:48). The current Roman Catholic position is theistic evolutionism while the Protestants and the evangelicals hold unto a dualistic position on Darwin's theory of evolution. Mixter said "Roman Catholic... Protestant scholars, found it necessary to accept more of evolutionary theory than the facts seem to demand. Thus with theistic presuppositions postulated, their position is most accurately described as theistic evolution" (Mixter 1960:188-189). The theistic evolutionists are yet to provide a satisfactory defence on how the creation of Adam and Eve correlates with Darwin's evolutionary theory according to which humans originated from some four or five organisms in a progressive order.

A former associate professor of evangelism at Trinity Evangelical Divinity School Illinois, Paul Little raised a similar concern of believing in Adam and Eve at the same time in evolution. He said that there is no correlation in these concepts: "[w]hen God breathed into Adam the breath of life, that set him apart from anything else God had made. This was a first! It also rules out the possibility suggested by some that people evolved from any animal ancestor" (Little 1988:121). The conceptualization of the word Adam have made some scholars to begin to argue that in the Bible, there are very few passages which describe Adam as an individual otherwise Adam portray the first group of people created by God and not strictly an individual (Metz 1967:63; Williams 1977:6-7; Nemesszhy \& Russel 1972:48). Other Christians emphasized 
the anti-evolutionary concepts while some have not taken a specific position on the subject.

\subsubsection{The Christian Anti-Evolutionists Movement}

Darwin's view on the origin of humans led to various kinds of responses among Christians. For example, the special creationists emphasized that God carried out the acts of creation in six literal 24-hour days. To them, the process of creation did not take God longer period of time; it was instantaneous without any compliance with any natural processes. Special creationists believe that God created all things out of nothing (ex nihilo) and that faith is the basis for accepting or rejecting the biblical account of creation (Hebrew 11:3). D.G. Jones adds:

Special creation today generally starts with the proposition of the creation of the world in six 24-hour days a few thousand years ago. This series of recent creative acts produced a world and its array of living things, which are usually defined as instantaneous and involve neither natural processes nor the use of any pre-existing materials (Jones 1987: 210).

Special creationists are finding it very difficult to accept the scientific idea about the origin of man and the earth because they believe that scientific discoveries are liable to change. Jones said that some fossils previously found to support Darwin's concept of evolution have now turned out to be in support of the special creation. Jones regarded this development as one of flaws of an absolute belief in science (Jones 1987:197). Many evangelical churches in the especially in the nineteenth century believed in the special creation account: “... some highly intelligent evangelical' scholars interpret the Genesis account as describing twenty-four-hour-days" (Wright \& Jones 1987:122, 208). The formation of the fundamentalist movement which gained recognition in the 1920 s in 
the United State of America was aimed at preserving the Scriptures against Darwin's view according to which humans emerged from brutes (Fundamentalism 1974:396).

The fundamentalist pursuit against evolution led to the popular Monkey or Scopes Trial. The Scopes trial was the first trial ever broadcast by radio in America. It took place on $10^{\text {th }}$ July, 1925 at Dayton, Tennessee (Hopkins 2003). It all started in 1919 when a fundamentalist group, the World's Christian Fundamentals Association (WCFA), decided to confront liberalism by attacking the teaching of evolution in tax-supported schools in the U.S.A. The government of Tennessee had at that time put an act against the teaching of evolution into law. The secretary of the American Civil Liberties Union saw in a news item a law prohibiting the teaching of evolution in tax-supported schools within Tennessee and she drew the attention of her director Roger Baldwin who promised to finance any teacher who will break the law by teaching the scientific theory of evolution (Davidheiser 1969:88).

John Thomas Scopes, a teacher in a local high school, though he had never previously taught evolution, but for the sake of Roger Baldwin took up the challenge by breaking the law. Scopes was arrested and put on trial. William Jennings Bryan, a former presidential aspirant and widely known fundamentalist, led the prosecution while the defense was led by Clarence Darrow, an agnostic and a celebrated criminal lawyer (Hopkins 2002). The death of Bryan on July 26, 1925 contributed to the defeat of the fundamentalists group and evolution is now taught in all American schools (Hopkins 2003).

The Scientific creationism or the creationists' movement emphasized that the best way to safeguard the truth of the biblical doctrines is to interpret the scripture literally, especially the 
Genesis account of creation (Schwarch 2002:164). Scientific creationism holds that:

\begin{abstract}
... the Biblical account of the origin of the earth is literally true, that the earth is much younger than most scientists believe, and that all species of organisms were individually created and appeared at their creation essential by the same as they appear (Raven \& Johnson 1999:420).
\end{abstract}

The modern creationist movement started in the 1880s with the works of McCready Price (1870-1963), an amateur geologist. Price in 1923 dismissed scientific findings on fossils which he thought contradicted the biblical-literal account of creation (Montgomery 2012:6). More so, the summer of 1980 marked a significant period in the history of the movement because it was the first time that the idea of advancing the course of creationism was raised and discussed in a newsletter. Many creationists in the USA went to court to try to ensure that the idea of creationism be taught in high schools alongside evolutionism because they taught that both creationism and evolutionism are science (Schwarch 2002:163). However, the creationists' views are not accepted by scientist as rational. Agarwal, Hyland and Smith said: "[c]reationists are only able to deal with content of the evolutionary theory, and cannot conduct research that could challenge their own ideals... Creationists do not function in a logical manner" (Agarwal, Hyland \& Smith 1998). In addition, Raven and Johnson thought that the name "scientific creationism" is not science because their theory on creation cannot be experimented (Raven \& Johnson 1999:420). At a point in time, the creationist course of action amazed the members of the National Academy of Science and the National Association of Biology Teachers in the USA, to the point that these two associations convened a meeting and a conclusion was 
reached that the creationist idea should not be completely rejected. The Supreme Court in America in 1987 declared that creationism could be taught on a voluntary basis and at that time between 30 and 69 percent of public school teachers introduced creationism into their curricula (Schwarch 2002:164).

Professor David R. Montgomery of the Quaternary Research Center and Department of Earth and Space Sciences, University of Washington said that creationism is not science and should never be regarded as science. He noted that contrary to science, creationism dissociate reason as a means of obtaining knowledge (Montgomery 20123:8). At present, the creationist campaign is not based only in North America but in some other parts of the world. In Europe for instance, Arthur E. Wilder-Smith (1915-1995) became "Europe's leading creationist" (Schwarch 2002:384). The late 1970s was when the creationists became established in Germany and began a monthly publication called Factum. Many books have been written by creationists in order to advance their cause (Schwarch 2002:164). Today, the creationist movement has varied views. Not all creationists are anti-evolutionist. Montgomery said that many creationists now believe in evolutionary processes of the earth and human origins (Montgomery 2012:8).

Christian anti-evolutionists believe that the biological evolution of man contradicted the biblical teaching about the creation of man on the sixth literal days (Genesis 1:21-27; 2:7) (Nemesszhy \& Russel 1972:10). Writing against Christian anti-evolutionists, Bernard Ramm said that Christian anti-evolutionists have no adequate answers and reasons to refute biological evolution (Davidheiser 1969:361). In fact, recent research on Genesis I conducted by some Christian scientists 
who are theistic evolutionists shows that creation and evolution do not contradict each other. These Christian scientists maintained that "...Genesis 1 is a register of descent, and by "evolution" we first mean descent of all life from a common ancestor" (Rust 1999:232-233).

The major contention between Christian evolutionists and anti-evolutionists lies on the concept the Day or the Days of Creation written in Genesis. Christian evolutionists regard the biblical days of creation to mean 6 literal days while Christian anti-evolutionists believe that the biblical days of creation meant thousands and millions of years (Chan 1997:43). A biologist, Rupert Sheldrake said that the creation of the Sun and Moon which only appeared on the fourth 'day' indicates that the biblical days are not supposed to be interpreted as literal days:

The main discrepancy is that in Genesis, the Sun and Moon appear only on the fourth 'day.' But this in self is significant in that it shows that the term 'day' is not to be taken literally, for it could not possibly have a literal meaning if the Sun, by rising or setting of which days are measured, did not yet exist, according to the very same text (Sheldrake 1984:22).

He added that there are many other biblical passages which indicate that human measurement of time differs from that of God (Psalms 90:4; 2 Peter 3:4). He said that the argument between Christian evolutionists and Christian anti-evolutionists is strictly limited to the conceptualization of the 'day' of creation. Sheldrake indicated that "[t]here seem to be no good grounds, even religious ones, for rejecting the theory of evolution by descent" (Sheldrake 1984:22). 


\section{CONCLUSION}

The emergence of various Christian groups that interprets the Genesis creation account differently are not in fierce conflict with each other as it was in the early 1860s. Thorough researches on the theory of evolution have contributed to making many conservative Christians to accept the theory. For example, Asa Gray, a conservative evangelical Christian, at first saw no compatibility between theistic evolution and the evangelical Christian faith. But in 1873 after a thorough study of Darwin's theory of evolution, he became Darwin's disciple: "... evolution is not so bad since an evangelical Christian like Asa Gray could be an evolutionist" (Davidheiser 1969: 76-77, originally from B. Ramm 1955:264-265). Mixter said "Roman Catholic... Protestant scholars, found it necessary to accept more of evolutionary theory than the facts seem to demand. Thus with theistic presuppositions postulated, their position is most accurately described as theistic evolution" (Mixter 1960:188189).

Furthermore, the seeming conflicts which exist or existed between Christian evolutionists and Christian anti-evolutionists have been regarded by many scholars as a conflict of worldview or perspective and not the conflict of science and faith. Chittick admonished Christians that the subject: "... is not a matter of science verses religion; one may be religious and hold either worldview. It is a matter of one belief system in conflict with another because they come from different starting assumptions" (Chittick 1987:267-268). Some Christians advocate that the purpose of creation is for the recognition of the Creator and that the Bible is not meant to explain the technical-know-how of the creation account (Genesis 1 \& 2, Hebrews 1:3). Burke and Barclay said that regarding God strictly as a creator who created spontaneously or instantaneously limits God sovereignty to create in process and that 
regarding God in strict terms as one who can only create in process is a limitation of God sovereignty to create instantaneously (Burke \& Barclay 1987:19). More so, Chan contends that "... whether we believe God created man in a moment of time or by a long process, it is in both cases a miracle that there is such a unique creature called man" (Chan 1997:41).

The debate on creation and evolution became volatile in 1859 due to Darwin's publication On Origins of Species. The book have also made some Christians to think that Darwin advocated or denounced God by making them to debate and rethink the creation account Indeed at the later part of his life, he became an agnostic. Notwithstanding, Darwin ought to be regarded as a hero not because he was a Christian but because he generated a debate that brought Christians and scientists together into academic reason. His theory of evolution since 1859 has brought the Church into critical thinking to the point that, a better understanding of the Genesis account of creation is now observed. Darwin did not divided the Church rather his theory of evolution have enlightened the Church and have contributed to defining using biological science the mutuality that exist between science and faith.

\section{Bibliography}

Agai, M. Jock. "An archaeological search for the emergence of early humans in West Africa" HTS Teologieses Studies/Theological Studies 70(3) Art.\#2033,http://dx.doi.org/10.4102/hts.v70i3.2033 (1-7), 2016.

Agarwal, Sandeep, Sammy Hyland and Michael Smith, "The Neodarwinist Evolutionary Theory of Human Origin" Revised February 1998.

Boer, Harry R., A Short History of the Early Church. Ibadan: Daystar Press, 1976.

Burke, Derek and Oliver Barclay R., (eds.), Creation and Evolution: When Christians Disagree. Leicester: Inter-Varsity Press, 1987.

Chan, Simon, Man and Sin, An Independent-Study Textbook. $2^{\text {nd }}$ ed. Texas: ICI University Press, 1997.

Chittick, E. Donald. The Controversy: Roots of Creation Evolution Conflicts. Portland: Multonomah Press, 1984. 
CNN, "Britain's 10 Great Men of the Nineteenth Century," 2003.

Cunningham, P. William \& Barbara Woodworth Saigo. Environment Science: A Global Concern. Chicago: Wm C. Brown Publishers, 1990.

Davies, L, 2014, "Pope Francis: Evolution and Creation both Right," Vanguard, 29 October from http:www.theguardian.com/world/2014/oct/28/pope-says-evoluti... [Accessed 11/6/2015].

"Darwin," Encyclopedia Americana, v. X. Danbury: Carolier Incorporated, 1987.

"Darwin," The New Book of Knowledge, Vol. 4. New York: Grolier Inc., 1979.

Dawkins, Richard, "Neodarwinism," 2004.

Darwin, Charles. Origin of Species by Means of Natural Selection. In the Great Book of the of the World vol. VII; No. 49, R. Huchins, J. Adler et al (eds.), Chicago: Encyclopedia Britannica Inc., 1952.

The Descent of Man and Selection in Religion to Sex. In the Great Book of the world vol. VII; No. 49, R. Huchins, J. Adler et al (eds.), Chicago: Encyclopedia Britannica Inc., 1952.

Derek Williams ed., "Adam" in New Concise Bible Dictionary (Leicester: Inter-Varsity Press, 1977), pp. 6-7.

Dowley, Tim and John Y.H. Briggs, eds. A Lion Handbook: The History of Christianity. Oxford: Lion, 1990.

Davidheiser, Bolton. Evolution and Christian Faith. Grand Rapids: Baker Book House, 1969.

"Evolution," Encyclopedia Americana, Vol. X. Danbury: Carolier Incorporated, 1987.

"Fundamentalism," The New Dictionary of the Christian Church. Exeter: The Paternoster Press, 1974.

Lamoureux O. Denis, “Theological Insight from Charles Darwin” 2015, 211.

Grigg, Russell. "Darwin's arguments against God: How Darwin rejected the doctrines of Christianity" from http://creation.com/darwins-arguments-against-god [Accessed 4 April, 2017].

Hopkins, Mark. Lectures on the Crisis of Liberalism and the Rise of NeoOrthodoxy $1890-1940)$, Bukuru, TCNN: $23^{\text {rd }}$ January and $27^{\text {th }}$ February, 2003.

Jones D.G., "Issues and Dilemmas in the Creation-Evolution Debate", Creation and Evolution: When Christians Disagree, Burke, Derek and Oliver Barclay R.,(eds.), Creation and Evolution: When Christians Disagree. Leicester: Inter-Varsity Press, 1987.

Little, Paul. Know Why You Believe. Illinois: Inter-Varsity Press, 1988. 
Metz, Johannes B., ed., The Evolving World and Theology; Concilium Theology in the Age of Renewal. XXVI,New York: Paulist Press, 1967.

Mixter, Russel L. Evolution and Christian Thought Today. Grand Rapids: Wm B. Eerdmans, 1960.

Montgomery, R. David, "The Evolution of Creationism' GSA Today, November 2012 , v. 2, no. 11, doi:10.1130/GSATG158A.1., 4-8.

Nemesszeghy, Ervin and John Russel. Theology of Evolution, Theology Today Series Number Six. Cork: Mercier Press, 1972.

Ojo, A., "Yoruba Omo Oduduwa: Papers on Yoruba people, language, and culture," from http://www.uga.edu/aflang/YORUBA/ODUDUWA.htm. 1999, [Accessed 9 June 2008].

Overman, Richard H. Evolution and the Christian doctrine of creation: A Whitedian interpretation. Philadelphia: The Westminster Press, 1952.

Oyebade, A., "Reconstructing the past through oral tradition," Understanding Yoruba life and culture, in N. S. Lawal, M. N. O. Sadiku \& A. Dopamu (eds.), African World Press. Trenton, 2004, 51-62.

Paley, Williams. "The Teleological Argument" in Reading for Philosophical Inquiry: A Brief Introduction, (1-8), [n.d].

Ramlingam Sarojini T. Modern Biology for Senior Secondary School. New ed. Onitsha: African - Feb. Publishers Limited 2001.

Raven, Peter H. and George B. Johnson, Biology. $5^{\text {th }}$ ed. New York: WCB McGraw-Hill, 1999.

Rust, Peter and Armin Held. "Genesis Reconsidered" Perspectives on Science and Christian

Faith: Journal of the American Scientific Affiliation, Vol. 51, No. 4, December 1999, 230-243.

Schwarz, Hans. Creation. Grand Rapids: William B. Eerdmans, 2002.

Sheldrake Rupert, "Evolution," Thinking the unthinkable: Ideas that Overturn Conventional Thought. Peter Brookesmith (ed.), London: Orbis Publishing, 1984.

Veldsman, P. Daniël. "Welc(h)omo Naledi'! What does our newest relative have to say to us?" HTS Teologieses Studies/Theological Studies 72(4), a3388.http://dx.doi.org/10.4102/hts.v72i4.3388, (1-7), 2016.

Welch, Claude A. et al Biological Science: Molecules to Man Boston: Houghton Mifflin Company, 1963.

Williams Blair, Michael P. Clough, Matthew Stanley \& James T. Colbert, "Charles Darwin: A Gentle Revolutionary," 2016.

Williams, William A. Evolution Mathematically Disproved. New Jersey: William A. Williams, 1928.

Wright \& Jones, "The Origin of Man and Issues and Dilemmas in the CreationEvolution Debate", Creation and Evolution: When Christians Disagree, Burke, Derek and Oliver Barclay R.,(eds.), Leicester: Inter-Varsity Press, 1987, 122, 208.

Wyhe van John, "Chares Darwin's Cambridge Life 1828-1831" Journal of Cambridge Studies, Vol. 4. No. 4 December 2009, 2-13. 